Agro-Science Journal of Tropical Agriculture, Food, Environment and Extension Volume 8 Number 2 Mav 2009 pp $84-89$

ISSN 1119-7455

\title{
INCOME AND CROP DIVERSIFICATION AMONG FARMING HOUSEHOLDS IN A RURAL AREA OF NORTH CENTRAL NIGERIA
}

\author{
Ibrahim, H., Rahman, S.A., Envulus, E.E and Oyewole, S.O \\ Department of Agricultural Economics and Extension Nasarawa State University, Keffi \\ PMB 135,Lafia, Nigeria.
}

\begin{abstract}
Income and crop diversification have been identified as essential strategies for raising income and reducing rural poverty. Both strategies were analyzed based on empirical data collected from rural households. The analysis was done using the Simpson Index of Diversity (SID) and Ordinary least square (OLS) regression analysis. The results revealed that diversification into a number of income sources and crops grown were very high. The determinants of income diversification were number of children less than 12 years old, number of adults above 60 years old, availability of electricity in the household and distance from local market. The determinants of crop diversification were, age and level of education of the household head, number of extension visits, availability of tractor hiring services and returns from crop production. Most households occupations in the study area were no longer agriculture based, however there willingness to diversify was significantly influenced by their socioeconomic characteristics.
\end{abstract}

Key words: Income, Crop, Diversification, Rural area, Households

\section{INTRODUCTION}

Income diversification refers to an increase in the number of sources of income or the balance among the different sources. Thus, a household with two sources of income would be more diversified than a household with just one source, and a household with two income sources, each contributing half of the total, would be more diversified than a household with two sources, with one that accounts for $90 \%$ of the total (Joshi, et al; 2003). Income diversification is defined as the process of switching from low value crop production to a higher value crop, livestock and non-farm activities. "High value crops" are often defined in terms of the value per unit of weight; it is probably more useful to define them as crops that generate high economic return per unit of labour and land. Income growth in an agricultural economy can come from various resources. Distinction can be made between growth in crop income, non-crop agriculture income (livestock, fisheries, and forestry) and non-agriculture income which includes both off-farm wage labour and nonfarm self employment (Escobal, 2001). Given that semi subsistence farmers often focus on production of staple food crops, the switch to non-crop activities is often referred to as income diversification. Crop diversification refers to growing many crops at the same time. It is also concerned with the switch from subsistence food production to commercial agriculture.
Rural households in many different countries have been found to diversify their income sources allowing them to spread risk and smoothen consumption (Chibnik, 1994; Ellis, 1998; Reardon, Delgado and Milton, 1992; Valdivia, Dunn and Jette, 1996). This is often necessary in agriculture based peasant economies because of risks such as variability in soil quality, household and crop diseases, price shock, unpredictable rainfall and other weather related events.

Income diversification can be achieved by producing a variety of crops and/or pursuing off-farm employment. According to the World Bank (1996), 52\% of Nigerians live on less than a dollar per day. In addition to the high incidence of poverty, most rural areas of the world are characterized by poor infrastructure, low level of urbanization, low population density and a very important agricultural sector (Minot, Epprecht, Anh and Trung, 2006). In addition to a rapid economic growth, a sustained and widespread growth in household income through diversification is a necessary condition for any developmental strategy for such areas (Minot et al., 2006). The aim of this study was to provide information that will assist policy makers in designing rural development and public investment policies that will help rural households raise their income through diversification. The specific objectives were to (i) examine the diversity in income sources of 
the households; (ii) examine the diversity in crop production of the households; and (iii) identify the determinants of crop and rural income diversification.

\section{MATERIALS AND METHODS}

The study was carried out in Nasarawa Eggon area in the North central Nigeria. The area is comprised of five districts namely Umme, Alogani, Alizaga, Agungi and Nasarawa Eggon with an estimated land of about $2035 \mathrm{sq} \mathrm{km}$. The area lies approximately between latitude $7^{\circ}$ and 9 North and longitude $7^{0}$ and 10 East. It has a projected population of about 89,787 people (NPC, 2005). About 70\% of the population is made up of subsistence farmers who cultivate crops such as yam, maize, sorghum, millet, and cowpea. The climate of the area is of the savannah type with two major seasons; the rainy season starting from the late April to late October and a dry season, which starts with harmattan from early November to late March. Primary data were used for the study and were collected with the aid of an interview schedule administered by trained enumerators to 100 household heads selected from the five districts in the study area i.e. 20 households heads per district. The households were earlier identified from a reconnaissance survey to have at least two income sources. Data were collected on socio economic variables, income and income sources and types of crops grown over a period of one month.

\section{Analytical techniques}

The Simpson index of diversity:

The Simpson index of diversity (SID) is widely used to measure the biodiversity of an ecosystem and is expressed as follows;

$\mathrm{SID}=1-\sum \mathrm{p}_{\mathrm{i}}^{2}$

Where;

$\mathrm{p}_{\mathrm{i}}=$ proportion of organisms classified in a species.

$\Sigma=\quad$ Summation sign

The SID can also be interpreted as the probability that two randomly selected organisms will be from the same species. Joshi et al (2003) adopted the SID to compare crop diversification in several South Asian countries. In this study, it was used to measure income and crop diversity, interpreting $\mathrm{p}_{\mathrm{i}}$ as the proportion of income from source "i" or crop "i". If there is just one crop or source of income, $p_{i}=1$ and SID $=0$. As the number of crops/income sources increases, the share " $p_{i}$ " declines as does the sum of the squared share, so that SID approaches 1 . If there are $\mathrm{K}$ sources of income then SID falls between zero and $1-1 / \mathrm{K}$. The closer SID is to zero, the more the specialization, and the further it is from zero, implies the more the diversification.

\section{Multiple regression analysis:}

Multiple regression analysis was used to identify the determinants of income and crop diversification. Two separate regression models were specified in their explicit forms as follows;

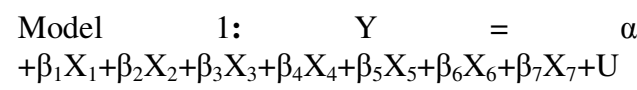
Where:

$$
\begin{aligned}
\mathrm{Y}= & \text { number of income sources in the } \\
& \text { household (actual number) } \\
\alpha= & \text { constant term } \\
\beta_{1}-\beta_{7}= & \text { regression coefficients } \\
\mathrm{X}_{1}= & \text { age of household head (years) } \\
\mathrm{X}_{2}= & \text { years of education of household } \\
& \text { head (no. of years) } \\
\mathrm{X}_{3}= & \text { total farm size of household (ha) } \\
\mathrm{X}_{4}= & \text { number of children under } 12 \\
& \text { years old (actual number) } \\
\mathrm{X}_{5}= & \text { number of adults over } 60 \text { years } \\
& \text { old (actual number) } \\
\mathrm{X}_{6}= & \text { availability of electricity in the } \\
& \text { household (dummy: yes }=1, \\
& \text { No=0) } \\
\mathrm{X}_{7}= & \text { distance from a local market } \\
& (\text { Km) } \\
\mathrm{U}= & \text { error term }
\end{aligned}
$$

Model 2: $Y=\alpha+\beta_{1} X_{1}+\beta_{2} X_{2}+\beta_{3} X_{3}+\beta_{4} X_{4}$ $+\beta_{5} \mathrm{X}_{5}+\beta_{6} \mathrm{X}_{6}+\beta_{7} \mathrm{X}_{7}+\beta_{8} \mathrm{X}_{8}+\beta_{9} \mathrm{X}_{9}+\mathrm{U}$

Where;

$\mathrm{Y}=$ number of crops grown (actual number)

$\alpha=$ constant term

$\beta_{1}-\beta_{9}=$ regression coefficients

$\mathrm{X}_{1}=$ age of household head (years)

$\mathrm{X}_{2}=$ membership of cooperative society

By household head (years)

$\mathrm{X}_{3}=$ years of education household head (no. of years)

$\mathrm{X}_{4}=$ total household farm size (ha)

$\mathrm{X}_{5}=$ extension visit (number of times/month)

$\mathrm{X}_{6}=$ distance to a local market $(\mathrm{Km})$

$\mathrm{X}_{7}=$ availability of tractor hiring services (dummy: yes $=1$, no $=0$ )

$\mathrm{X}_{8}=$ annual returns from crop production (

$\mathrm{X}_{9}=$ road condition $($ dummy: $\operatorname{good}=1, \mathrm{bad}=$ $0)$

$\mathrm{U}=$ error term

It is assumed that for a given observation, the error term (U) is a random variable with a probability distribution that is normal with a mean of zero and a constant standard deviation. The linear, semi-log and double $\log$ forms of the 2 models were tried and the lead equation (linear form) was selected based on the $\mathrm{R}^{2}$, $\mathrm{t}$ - statistics and the 
conformity of the sign of the estimated coefficients with apriori expectations.

\section{RESULTS AND DISCUSSION Diversity in sources of income}

To examine the diversity of income sources, household income was divided into five categories: crop, livestock, fisheries, nonfarm enterprises and wage income. The simplest measure of income diversity was the average number of income sources (of the five listed here) that households had. It was observed that rural households in the study area had an average of 2 sources of income (Table 1). The value of the SID was 0.82 . This is indicative of the fact that diversification was high as respondents adopted multiple income generating activities to manage risk and meet household consumption needs. In order words, households in the study area showed a tendency to increase the number of sources of income and the balance of income among sources. Carrying out two activities on the same farm might reduce cost of increased output if they are linked in the same way, because the production of one good reduces the unit cost of producing another good. For example, a household that raises livestock can often reduce the cost of feed by growing its own grain and fodder; raising livestock near crop reduces the cost of producing crops by providing an inexpensive source of organic fertilizer (Minot et al., 2006).

\section{Diversity in crop production}

The average number of crops grown out of the ten observed in the study area was five. This agrees with the findings of Minot et al. (2006) that rural households grow up to five or six crops. The findings in Table 1 indicated non-specialization among the respondents. The aim is to meet consumption needs, to reduce risk associated with weather or disease outbreak or for economy of scale. The SID value of 0.94 is further supportive of the above observation.

Table 1: Measurement of diversity in income sources and crop production

\begin{tabular}{lll}
\hline & Income sources & Crops grown \\
\cline { 1 - 2 } SID & Average number & \\
& 2 & 5 \\
& 0.82 & 0.94 \\
\hline
\end{tabular}

Determinants of income diversification From the regression analysis on Table $2,63 \%$ of the variation in the number of income sources was explained by the variables included in the model. The number of children less than 12 years had a positive but significant coefficient. As expected, households with a small proportion of children under 12 years tended to have a larger number of income sources. Controlling for farm size, the marginal product of additional family labour in crop production declined as the household size increased, making it more likely that alternative source of income would be attractive. Furthermore with a large number of working age adults, it is more likely that the household will have a range of skills and inclination that allowed income diversity at the household level, even if household members are specialized individually (Minot et at., 2006).

Table 2: Determinants of Income diversity

\begin{tabular}{llll}
\hline Variables & $\begin{array}{l}\text { Regression } \\
\text { Coefficient }\end{array}$ & $\begin{array}{l}\text { Standard } \\
\text { Error }\end{array}$ & T value \\
\hline Constant term & 2.256 & 0.406 & 0.00 \\
Age of household & 0.642 & 0.008 & $0.408^{\mathrm{NS}}$ \\
Years of education Household & -1.058 & 0.13 & $0.936^{\mathrm{NS}}$ \\
Head & 1.593 & 0.187 & $0.519^{\mathrm{NS}}$ \\
Total farm size of Household & 0.282 & 0.055 & $0.86^{* * *}$ \\
Number of children under 12 & -4.026 & 0.062 & $0.002^{*}$ \\
Number of adult above 60 years & -2.157 & 0.182 & $0.066^{* * *}$ \\
Availability of electricity & & & \\
in the Household & -9.693 & 0.012 & $0.000^{*}$ \\
Distance from local market & & & \\
\hline
\end{tabular}

$\mathrm{R}^{2}=0.63$

F- Ratio $=83 * * *$

The number of adults above 60 years was also significant. The negative sign implies that larger households with small proportion of elderly people tended to have a larger number of income sources. A large household with a high proportion of working age adults implies more labour for income generating activities. If this labour is allocated to crop production, the higher labour intensity will probably be reflected in higher yield and greater per hectare crop income (Joshi et al., 2003). Availability of electricity in the household was significant but negatively related to the number of income sources. Electricity makes it possible for household members to participate in some form of self-employment. Thus, households with electricity have more diverse income sources and a larger share of income from nonfarm activities. A household with electricity should earn more of its income from non-farm activities than one without it. Distance to local 
Income and Crop Diversification Among Farming Households

Table 3: Determinants of crop diversity (number of crops grown)

\begin{tabular}{llll}
\hline Variables & Regression Coefficient & Standard Error & T value \\
\hline Constant term & 6.247 & 0.768 & 0.000 \\
Age of Household Head & 2.201 & 0.015 & $0.085^{* * *}$ \\
Membership of cooperative & -4.641 & 0.059 & $0.436^{\text {NS }}$ \\
Education of Household Head & 6.270 & 0.030 & $0.037^{* *}$ \\
Total farm size & 0.122 & 0.138 & $0.378^{\text {NS }}$ \\
Extension visit) & 7.739 & 0.255 & $0.005^{*}$ \\
Distance to local market & -1.634 & 0.025 & $0.513^{\text {NS }}$ \\
Available of tractor hiring & 0.614 & 0.429 & $0045^{* *}$ \\
Return from crop production & -2.228 & 0.000 & $0.095^{* * *}$ \\
Road net work condition & -1.068 & 0.405 & $0.010^{*}$ \\
\hline
\end{tabular}

$\mathrm{R}^{2}=0.49$

F-Ratio $=9 *$

$*=$ Significant at $10 \%$ level

$* *=$ Significant at $5 \%$ level

$* * *=$ Significant at $1 \%$ level

$\mathrm{NS}=$ Not significant

market was significantly related to income diversification. The negative sign implies that the larger the distance the lesser the tendency of households to diversify and vice versa. Households with poor access to market face higher transaction cost in buying from or selling to the national economy (Omamo,

1998). It is expected that households that have poor market access to be more specialized in crop production, have fewer non-farm activities and fewer income sources. Since transaction cost reduces the return from market sale, it is expected that remote households will get a smaller share of the crops produced. The education of household head was not significant even though previous studies (Pedersen and Annou 1999; Joshi et al., 2003; Minot et al., 2006) had confirmed that education may open the door to a number of different economic activities, either because of formal requirement for wage earning position or because education facilitates learning about new self employment opportunities. Farm size had a positive relationship with diversification but was also not significant

\section{Determinants of Crop Diversification}

From the regression analysis on Table $3,49 \%$ of the variation in the number of crops grown was explained by the variables included in the model. The number of crops grown increased with the age of the household head. This seems to indicate that farmers try new crops as they gain more experience overtime. The educational level of household heads was positively related with the number of crops grown, thus highlighting the importance of knowledge and ability to absorb new information through extension services or other sources. As the number of years of education of the household's head increases so

does his work related skills and his ability to acquire new skills. Thus, it is expected that a high level of education will lead to a higher value crop production and more commercially oriented agriculture and greater participation in non-farm activities.

Increase in the frequency of extension visits implies that the more the household head has contact with extension agents, the more the tendency to diversify into crop production. This also implies that extension workers have an important role to play in creating awareness among farmers as well as educating them on the importance of diversification. The availability of tractor for the household also related positively and significantly with the number of crops grown. This means that the more the household head has tractor available for hire, the less the requirement for manual labour and the greater the extent of diversification. Household heads that have access to tractor should earn more from crop production as a result of the reduced drudgery of land preparation.

The higher the income derived from crop production by the household's head the more the tendency to diversify into crop production. An increase in the share of crop production was associated with lesser income diversity (as household specialized in crop production). A household with bad access roads face higher transaction cost in buying from or selling to markets. Since wage labour and non-farm enterprises are almost all market oriented, crop production can be for home consumption or for sale. As transaction cost reduces the returns from market sale it is expected that remote households will sell a smaller share of their crop production (Minot, 1999). Finally it is expected that remote households will have more diverse cropping pattern to meet diverse needs of household consumption. If a household head lives near a road that is impassible (bad road) he sells less crop output compared to a household head living near a road that is passable (good road) all season (Minot et al., 2006). Good road 
network also favours diversification because of low marketing cost, easy disposal of commodity, reduced risk and post harvest loses. High profit implies less diversification to other crops while lesser profit may induce farmers to diversify into new crops with an anticipated higher return. This is collaborated by the findings of Joshi et al. (2003).

\section{CONCLUSION AND RECOMMENDATIONS}

The study has shown that diversification into a number of income sources and crops grown are very high in the study area. Diversification can also help to relax credit or capital constraints among farmers. Similarly, the socio-economic characteristics of the respondents such as number of children under 12 years, number of adults above 60 years, availability of electricity in the household and distance from a local market influence the level of income diversification. Furthermore, the age and level of education of the household head, extension contact, availability of tractor hiring services, returns from crop production and road condition significantly determine the level of crop diversification. Based on the findings, the followings are recommended;

1. Policies and programmes to raise the income of the poor households must also focus on increasing the income from crop production. This can be achieved by improving agricultural extension delivery in the country. Therefore, there is a need for the State governments to pay more attention to agricultural extension programmes through the recruitment and training of adequate extension workers to meet the needs of the nation.

2. Programmes to help farmers raise farm income through crop production should also focus on providing tractor hiring services in order to reduce drudgery and to increase the hectarage and income of the poorest households.

3. There is a need for government to provide more rural roads and rehabilitate bad ones in order to reduce the high transaction cost of buying from or selling to markets, as transaction cost reduces the returns from market sales.
4. Power supply to rural areas should be clearly articulated in the power supply component of the seven point agenda of the Federal Government. This will go along way to aid the setting up of cottage industries and the creation of non-farm employment opportunities.

\section{REFERENCES}

Chibnik, M. (1994) Risky Rivers: The Economics and Politics of Flood Plain Farming in Amazonia. University of Arizona Press. Tuscon

Ellis, F. (1998) Household livelihood strategies and rural livelihood diversification Journal of Development Studies, 35(1):1-38

Ersado, L. (2003) The determinants of nonfarm income diversification in rural Peru. World Development 29(30): 497-508

Escobal, J. (2001) The determinants of nonfarm income diversification in rural Peru. World Development, 29(30):497-508

Joshi, P.K., Gulati, A.A., Birthal, P.S. and Twari, L. (2003) Agriculture diversification in South Asia: Pattern, determinants and policy implications. Discussion Paper No. 57. Market structure studies division. International Food Policy Research Institute. Washington D.C.

Minot, N. (1999) Effectiveness of transaction cost on supply response and market surplus: Simulation using nonseparable household models. Discussion paper No. 36. Market Structure Studies Division, International Food Policy Research Institute Washington D.C.

Minot, N., Epprecht., M., Anh., T.T.T. and Trung, L.Q. (2006) Income diversification in the northern uplands of Vietnam': Research report No. 145. International Food Policy Research Institute, Washington D.C.

National Population Commission, (2005) National Population and Housing Census Report Federal Republic of Nigeria 
Income and Crop Diversification Among Farming Households

Omamo, S. (1998) Transport costs and smallholder cropping choices: An application to Siaya District,

Kenya. American Journal of Agricultural Economics, 80(February):116-123

Pedersen, G. and Annou, M. (1999) Rural household income diversification in Vietnam. Quarterly Journal of International Agriculture, 38(2):140149

Reardon. T., Delgado, D and Milton, P. (1992) Determinants and effects of income diversification amongst farm households in Burkina Faso. Journal of Devt. Studies, 28(20):264-296
Valdivia. C., Dunn, E. and Jette, C. (1996) Diversification as a risk management strategy in an Andean agro pastoral community' American Journal of Agric Economics, 78(5):13-34.

World Bank (1996). Poverty in the Midst of Plenty. The challenge of growth with inclusion. A world Bank poverty assessment, population and human resource division. West Africa Department, African Region Report No 14733. 